\title{
PELATIHAN KONSELING POST-MODERN BAGI GURU BK SEKOLAH MENENGAH PERTAMA DI KOTA SURABAYA
}

\author{
Oleh: \\ Bambang Dibyo Wiyono ${ }^{1}$, Tamsil Muis², Budi Purwoko ${ }^{3}$ \\ 1,2,3Universitas Negeri Surabaya \\ 1bambangwiyono@unesa.ac.id
}

\begin{abstract}
Abstrak
Kota Surabaya merupakan salah satu kota metropolitan di Indonesia. Kemajuan teknologi menimbulkan efek negatif yang kompleks melebihi manfaat dari teknologi itu sendiri terutama terkait pola hidup manusia dalam dimensi sosial budaya. Guru bimbingan dan konseling SMP Surabaya sebagai pendidik bisa mengambil peran untuk mengatasi kondisi tersebut. Salah satu layanan kuratif dalam bimbingan dan konseling adalah layanan konseling. Salah satu pendekatan konseling kekinian yakni pendekatan konseling post-modern yang terdiri dari konseling singkat berfokus solusi. Berdasarkan evaluasi proses dan hasil, peserta pelatihan konseling post-modern memberikan kesan positif dan mampu mempraktekkan konseling singkat berfokusi solusi di instansinya masing-masing.
\end{abstract}

Kata Kunci: Pelatihan, Konseling Post-modern, Guru BK SMP

\begin{abstract}
Surabaya is one of the metropolitan cities in Indonesia. Technological advances have complex negative effects beyond the benefits of the technology itself, especially with regard to the pattern of human life in the socio-cultural dimension. Teacher guidance and counseling SMP Surabaya as educators can take a role to overcome these conditions. One of the curative services in guidance and counseling is a counseling service. One of the contemporary counseling approaches is the post-modern counseling approach that consists of short, solution-focused counseling. Based on the evaluation of the process and outcomes, post-modern counseling participants gave a positive impression and were able to practice brief counseling solutions in their respective instances.
\end{abstract}

Keywords: Training, Post-modern Counseling, Counseling Teacher in Junior High School

\section{PENDAHULUAN}

Kota Surabaya merupakan salah satu kota metropolitan di Indonesia. Status metropolitan tersebut berimplikasi terhadap kemudahan akses dalam kemajuan teknologi. Kemajuan teknologi ibarat dua sisi mata uang, di mana di satu sisi kemajuan teknologi memberikan banyak manfaat positif bagi manusia untuk mempermudah manusia dalam memenuhi kebutuhan hidupnya. Namun demikian disisi yang lain kemajuan teknologi menimbulkan efek negatif yang kompleks melebihi manfaat dari teknologi itu sendiri terutama terkait pola hidup manusia dalam dimensi sosial budaya.

Secara sosiologis, teknologi memiliki makna yang lebih mendalam daripada peralatan. Teknologi menetapkan suatu kerangka bagi kebudayaan non material suatu kelompok. Jika teknologi suatu kelompok mengalami perubahan, maka cara berpikir manusia juga akan mengalami perubahan. Di era digital ini, anak berimajinasi sesuai dengan apa yang ditayangkan televisi, apalagi yang menonton itu adalah anak-anak yang belum mampu membedakan antara yang nyata dan visual. Tuntutan melarang penayangan acara Smack Down di salah satu stasiun televisi adalah suatu contoh betapa besarnya akibat acara tersebut bagi kepribadian anak. Anak Sekolah Dasar dan Menengah yang meniru apa yang mereka tonton dan tidak segansegan berbuat sadis sehingga berakibat fatal bagi fisik dan bahkan ada yang meninggal (Bachtiar, 2012:224-225).

Deskripsi di atas merupakan kondisi kekinian peserta didik sebagai dampak kemajuan teknologi. Perubahan cara berpikir dan bertindak merupakan hasil konstruksi bahasa dan budaya yang secara tidak langsung bersamaan dengan kemajuan teknologi. Kondisi ini tentunya membutuhkan tindakan kuratif yang efektif. 
Guru bimbingan dan konseling SMP sebagai pendidik bisa mengambil peran untuk mengatasi kondisi tersebut. Salah satu layanan kuratif dalam bimbingan dan konseling adalah layanan konseling, yang mencakup layanan konseling individu dan layanan konseling kelompok. Layanan konseling termasuk dalam pelayanan responsif, yaitu merupakan layanan pemberian bantuan kepada konseli yang menghadapi kebutuhan dan masalah yang memerlukan pertolongan dengan segera, sebab jika tidak segera dibantu dapat menimbulkan gangguan dalam pencapaian tugas-tugas perkembangan. Konseling adalah suatu hubungan profesional yang dilakukan konselor untuk membantu konseli mendapatkan pengertian dan menjernihkan atau memperjelas pandangannya untuk dipakai sepanjang hidup sehingga konseli pada tiap kesempatan dapat menentukan pilihan yang berguna sesuai sifat esensial khusus sekitarnya (McLeod, 2009).

Sebagai kinerja utama dari keseluruhan layanan bimbingan dan konseling di sekolah, pelaksanaan layanan konseling sangat bergantung dari pelaksananya yaitu konselor. Konselor sekolah adalah tenaga profesional di bidang bimbingan dan konseling. Untuk itu seyogyanya dalam pemberian layanan konseling diberikan secara profesional pula.

Konselor memiliki tanggungjawab untuk memberikan layanan konseling profesional kepada para konseli dalam upaya membantu peningkatan prestasi dan pengembangan potensi diri pada siswa di sekolah. Secara teoritik untuk Indonesia, konselor tingkat SMP mempunyai persentase waktu pemberian layanan responsif (termasuk konseling) antara $25-35 \%$. Waktu yang diberikan terbatas dibandingkan dengan layanan yang lain yaitu layanan dasar (Depdiknas, 2007).

Konselor diharapkan memiliki kemampuan untuk terampil, menguasai, dan mengaplikasikan pendekatan konseling yang efektif dan efisien dalam rangka mewujudkan layanan konseling yang profesional di sekolah. Jadi, diperlukan satu pendekatan konseling yang memperhatikan aspek keefektifan dan efisiensi dalam mewujudkan perubahan konseling dalam membantu konseli menyelesaikan masalah yang dihadapi.

Salah satu pendekatan konseling kekinian yakni pendekatan konseling post-modern yang salah satunya adalah konseling singkat berfokus solusi Secara filosofis, pendekatan ini didasari oleh suatu pandangan bahwa sejatinya kebenaran dan realitas bukanlah suatu yang bersifat absolut namun realitas dan kebenaran itu dapat dikonstruksikan. Semua pengetahuan bersifat relatif karena selalu ditentukan oleh konstruk, budaya, bahasa atau teori yang kita terapkan pada suatu fenomena tertentu. Hal ini merupakan pandangan para penganut konstruktivisme sosial yang mengembangkan paradigmanya berdasarkan filosofis postmodern. Konstruktivisme sosial merupakan sebuah perspektif terapeutik dengan pandangan postmodern yang menekankan pada realitas konseli tanpa memperdebatkan apakah hal tersebut akurat atau rasional (Weishaar dalam Corey 2009: 375). Konstruktivisme sosial juga mengacu pada gagasan bahwa makna tentang fenomena atau peristiwa dibangun oleh orang-orang yang bekerja bersama-sama (Burr; Gergen dalam McLeod, 2009: 223).

Bagi orang-orang konstruktivisme sosial, realitas didasarkan pada penggunaan bahasa dan umumnya merupakan fungsi situasi di mana orang tersebut hidup (Corey, 2009: 375). Sedangkan dalam pemikiran postmodern, bahasa dan penggunaannya menciptakan makna dalam cerita-cerita yang disampaikan oleh individu. Dengan demikian akan terdapat banyak sekali makna-makna cerita sebanyak orang-orang menceritakan kisah tersebut dan masing-masing cerita tersebut adalah benar bagi orang yang menceritakannya.

Charlesworth \& Jackson (2004) menyatakan bahwa konseling singkat berfokus solusi cocok untuk setting sekolah karena mampu memberikan konseling yang efektif dan waktu yang lebih singkat. Konseling singkat muncul sebagai jawaban atas tuntutan kebutuhan layanan konseling yang mengutamakan kepraktisan, keefektifan dan keefisienan khususnya dalam hal keterbatasan waktu konseling. Konseling singkat pada dasarnya bukanlah pendekatan spesifik atau model yang berbeda/istimewa dari teori dan praktik lainnya, namun lebih menggambarkan pada terapi/konseling yang dibatasi waktu (time limited) di mana menggunakan kekuatan-kekuatan, memahami konteks masalah yang terjadi dan difokuskan untuk masa kini dan masa mendatang (McLeod, 2003 dalam Lines, 2012:10).

Adapun SMP yang akan dilibatkan dalam pelatihan ini meliputi: SMPN 15 Surabaya, SMPN 17 Surabaya, SMPN 22 Surabaya, SMPN 23 Surabaya, SMPN 28 Surabaya, 
SMPN 32 Surabaya, SMPN 34 Surabaya, SMPN 36 Surabaya, SMP Baitussalam Ketintang, SMP Muhammadiyah 1 Surabaya, MTs Nurul Hikmah Surabaya, dan SMP Hangtuah 4 Surabaya.

Berdasarkan uraian di atas, maka dapat disimpulkan bahwa mitra sasaran membutuhkan pelatihan pendekatan konseling kekinian yang efektif dan efisien yaitu pendekatan konseling post-modern. Pelatihan ini diperlukan untuk meningkatkan layanan konseling kepada peserta didik/konseli.

\section{METODE PELAKSANAAN}

Mengacu pada permasalahan yang dihadapi oleh mitra maka metode yang ditawarkan adalah:

1. Merumuskan masalah

Rumusan masalah pada mitra yaitu minimnya pengetahuan dan keterampilan dalam konseling post-modern sehingga pelaksanaan konseling selama ini belum efektif dan efisien. Bagaimana meningkatkan efektivitas konseling melalui pelatihan konseling post-modern.

2. Menentukan metode kegiatan yaitu: metode perancangan, pelatihan dan pendampingan.

3. Pelatihan konseling post-modern mitra untuk menambah pengetahuan dan keterampilan konseling bagi Guru BK SMP.

4. Pemantauan dan pendampingan setelah diberikan pelatihan pada mitra.

Pelaksanaan kegiatan pengabdian kepada masyarakat meliputi:

1. Koordinasi antar anggota pelaksana dengan pihak mitra dalam menentukan permasalan prioritas yang harus segera ditangani.

2. Pembuatan buku panduan konseling post-modern sesuai kondisi mitra.

3. Pelatihan

Tabel 1. Jadwal Pelatihan

\begin{tabular}{|c|c|c|c|}
\hline Hari/Tanggal/Tempat & Waktu & Materi Pelatihan & Pemateri/Instruktur \\
\hline \multirow{4}{*}{$\begin{array}{l}\text { Minggu, } 13 \text { Agustus } \\
2016 \text { di Lab. BK FIP } \\
\text { Unesa }\end{array}$} & $08.00-10.00$ & $\begin{array}{l}\text { Pendekatan konseling } \\
\text { post-modern }\end{array}$ & $\begin{array}{l}\text { Dr. Budi Purwoko, M.Pd. } \\
\text { Dr. Tamsil Muis }\end{array}$ \\
\hline & $10.00-12.00$ & $\begin{array}{l}\text { Konseling singkat } \\
\text { berfokus solusi }\end{array}$ & Bambang Dibyo W., M.Pd. \\
\hline & $12.00-13.00$ & ISHOMA & \\
\hline & $13.00-15.00$ & Praktik konseling & $\begin{array}{l}\text { Elisabeth Christiana, M.Pd. } \\
\text { Wiryo Nuryono, M.Pd. }\end{array}$ \\
\hline $\begin{array}{l}\text { Minggu, } 20 \text { Agustus } \\
2016\end{array}$ & $08.00-12.00$ & $\begin{array}{l}\text { Evaluasi dan tindak } \\
\text { lanjut }\end{array}$ & Tim \\
\hline
\end{tabular}

4. Evaluasi hasil pelatihan

Evaluasi kegiatan pelatihan didasarkan pada beberapa indikator secara langsung antara lain: pelaksanaan pelatihan lancar, antusias dari sasaran yang ditunjukkan dengan jumlah kehadiran dan banyaknya pertanyaan, serta semangat dalam mengikuti pelatihan, juga bertambahnya keterampilan dan pengetahuan peserta praktik konseling post-modern. Instrumen evaluasi terdiri dari:

a. Daftar presensi sasaran.

b. Angket kepuasan sasaran tentang pelaksanaan pelatihan.

c. Pemantauan setelah pelatihan untuk mengetahui keberhasilan dari pelatihan tersebut.
5. Pemantauan dan pendampingan untuk mempraktekkan hasil pelatihan di lembaga/sekolah masing-masing.

\section{HASIL DAN PEMBAHASAN}

Sebelum pelaksanaan pelatihan, tim pelaksana terlebih dahulu melakukan koordinasi dengan pihak mitra terkait prioritas permasalah yang dihadapi. Berdasarkan informasi dari mitra sasaran, kebutuhan akan pelatihan konseling post-modern khususnya konseling singkat berfokus solusi sangat dibutuhkan karena merupakan pendekatan baru dalam konseling yang efektif dan efisien.

Menindaklanjuti hasil koordinasi tersebut, tim pelaksanan menyusun buku panduan konseling singkat berfokus solusi. Buku 
panduan ini disusun untuk mempermudah mitra sasaran untuk memahami dan mempraktekkan saat diberikan pelatihan. Buku panduan konseling singkat berfokus solusi berisi:

1. Sejarah perkembangan

2. Penggunaan bahasa dalam pendekatan post-modern

3. Karakteristik konseling singkat

4. Hakikat manusia

5. Tahap-tahap konselingTeknik-teknik konseling

6. Contoh verbatim/skenario konseling

7. Lampiran-lampiran
Pelatihan konseling post-modern (konseling singkat berfokus solusi) bagi Guru BK SMP di Kota Surabaya dilaksanakan dalam dua pertemuan. Pertemuan pertama dilaksanakan pada hari Sabtu, 13 Agustus 2016 jam 08.00-15.00 WIB bertempat di Laboratorium Bimbingan dan Konseling Fakultas IImu Pendidikan Universitas Negeri Surabaya. Sedangkan, pertemuan kedua dilaksanakan pada hari Sabtu, 20 Agustus 2016 jam 08.00-12.00 WIB dengan tempat yang sama. Peserta yang berpartisipasi sejumlah 21 orang dengan rincian sekolah sebagai berikut:

Tabel 2. Rincian Asal Sekolah Peserta

\begin{tabular}{lcc}
\hline No. & Asal Sekolah & Jumlah Peserta \\
\hline 1 & SMPN 36 Surabaya & 2 orang \\
\hline 2 & SMPN 15 Surabaya & 1 orang \\
\hline 3 & SMPN 22 Surabaya & 2 orang \\
\hline 4 & SMPN 34 Surabaya & orang \\
\hline 5 & SMPN 17 Surabaya & 3 orang \\
\hline 6 & SMPN 28 Surabaya & 2 orang \\
\hline 7 & SMP Baitussalam Ketintang & 2 orang \\
\hline 8 & SMP Muhammadiyah 1 Surabaya & 1 orang \\
\hline 9 & MTs Nurul Hikmah Surabaya & 2 orang \\
\hline 10 & SMP Hangtuah 4 Surabaya & 21 orang
\end{tabular}

Pelatihan pertemuan pertama terbagi dalam tiga sesi yaitu: (1) pendekatan konseling postmodern; (2) konseling singkat berfokus solusi; (3) praktik konseling. Durasi waktu masingmasing sesi @ 2 jam (120 menit). Pada sesi pertama, Dr. Tamsil Muis dan Dr. Budi Purwoko memaparkan materi tentang pendekatan konseling post-modern dengan rincian: (a) sejarah perkembangan; (b) penggunaan bahasa dalam post-modern; dan (c) karakteristik konseling singkat.

Sesi kedua dilanjutkan dengan materi konseling singkat berfokus solusi oleh Bambang Dibyo Wiyono, M.Pd. Pemaparan materi terbagi menjadi tiga yaitu: (a) hakikat manusia; (b) tahap-tahap konseling; (c) teknik-teknik konseling. Setelah materi disampaikan beberapa peserta bertanya untuk memperdalam pemahaman.

Setelah istirahat, sesi ketiga dilanjutkan dengan praktik konseling singkat berfokus solusi yang dipandu oleh Elisabeth Christiana, M.Pd. dan Wiryo Nuryono, M.Pd. Sebelum praktek, peserta dibagikan contoh verbatim/skenario konseling singkat berfokus solusi. Peserta diminta berpasang-pasangan, satu berperan sebagai konselor dan satunya lagi berperan sebagai konseli. Peserta mempraktekkan skenario dengan panduan dari dua dosen pembimbing.

peserta diberi pengarahan untuk mempraktekkan pengetahuan dan keterampilan konseling singkat berfokus solusi di sekolahnya masing-masing. Setiap peserta diharapkan menangani masalah satu konseli dengan pendekatan konseling singkat berfokus solusi. Pelaksanaan konseling tersebut dibahas pada pelatihan pertemuan kedua.

Pelatihan pertemuan kedua dilaksanakan seminggu kemudian. Targetnya yaitu evaluasi dan tindak lanjut pelaksanaan konseling singkat berfokus solusi. Masingmasing peserta melaporkan hasil praktek di sekolahnya serta menyampaikan hambatan yang dihadapi. Hambatan-hambatan tersebut dibahas berdasar skala prioritas dalam pelaksanaan konseling singkat berfokus solusi. Hambatan pelaksanaan konseling singkat berfokus solusi, meliputi kemampuan teknik dasar konseling dan konseli masih berkutat dengan masalah. 
Pasca pelatihan dilaksanakan, peserta diminta mengisi angket kepuasan/ evaluasi dan umpan balik pelatihan konseling singkat berfokus solusi. Berdasarkan hasil analisis diperoleh data sebagai berikut.

Tabel 3. Evaluasi Hasil Pelatihan

\begin{tabular}{lll}
\hline No. & \multicolumn{1}{c}{ Aspek/ Indikator } & \multicolumn{1}{c}{ Hasil } \\
\hline 1 & Kemampuan narasumber & $63,64 \%$ sangat baik \\
& & $36,36 \%$ baik \\
\hline 2 & Materi pelatihan & $54,55 \%$ sangat baik \\
& & $45,45 \%$ baik \\
\hline 3 & Metode pelatihan yang digunakan & $90,91 \%$ baik \\
& & $9,09 \%$ sangat baik \\
\hline 4 & Waktu pelaksanaan pelatihan & $54,55 \%$ cukup baik \\
& & $36,36 \%$ baik \\
& & $9,09 \%$ sangat baik \\
\hline 5 & Konsumsi selama pelatihan & $72,73 \%$ sangat baik \\
& & $27,27 \%$ baik \\
\hline 6 & Tempat pelaksanaan pelatihan & $54,55 \%$ sangat baik \\
& & $45,45 \%$ baik \\
\hline 7 & Panitia penyelenggaran pelatihan & $45,45 \%$ sangat baik \\
& & $36,36 \%$ baik \\
& & $9,09 \%$ cukup baik \\
& & $9,09 \%$ kurang baik \\
\hline 8 & Relevansi pelatihan dengan kebutuhan & $72,73 \%$ baik \\
& peserta & $27,27 \%$ sangat baik \\
\hline
\end{tabular}

Pelatihan konseling post-modern (konseling singkat berfokus solusi) bagi Guru BK SMP di Kota Surabaya merupakan kegiatan pengabdian untuk memfasilitasi kebutuhan mitra terkait konseling yang efektif dan efisien. Secara teoritik untuk Indonesia, konselor tingkat SMP mempunyai persentase waktu pemberian layanan responsif (termasuk konseling) antara 25-35\%. Sesuai dengan pendapat Charlesworth \& Jackson (2004) menyatakan bahwa konseling singkat berfokus solusi cocok untuk setting sekolah karena mampu memberikan konseling yang efektif dan waktu yang lebih singkat.

Penyusunan modul/panduan pelatihan berdasarkan literatur yang komprehensif yaitu Corey (2009), Capuzzi \& Gross (2009), Flanagan \& Flanagan (2004), Lines (2012), Seligman (2006). Secara umum panduan memuat dua bagian yaitu pembahasan tentang pendekatan konseling post-modern dan pembahasan tentang konseling singkat berfokus solusi. Selanjutnya, untuk mempermudah konselor dalam mempraktekkan, panduan ini disertai dengan contoh verbatim dan instrumen konseling.

Pelatihan ini meliputi beberapa kegiatan yaitu:

1. Tahap persiapan; penyusunan
modul/panduan pelatihan.
2. Tahap pelaksanaan: terdiri dari dua pertemuan yaitu pertemuan pertama berisi pemaparan materi dan simulasi, sedangkan pertemuan kedua berisi laporan pelaksanaan konseling di instansinya masing-masing.

3. Evaluasi: evaluasi terhadap proses dan hasil pelatihan.

Berdasarkan hasil evaluasi hasil dapat disimpulkan bahwa peserta memberikan penilaian dengan kategori 'sangat baik' pada 7 aspek dan kategori 'baik' pada 1 aspek terakhir. Hal ini menunjukkan bahwa peserta memberikan kesan positif terhadap fasilitas dan pelaksanaan pelatihan.

Sedangkan pada hasil monitoring diperoleh data bahwa hambatan yang dialami peserta saat mempraktekkan konseling di instansinya masing-masing hanya dua yaitu teknik dasar konseling dan konseli masih berkutat dengan masalah. $\mathrm{Hal}$ ini menunjukkan bahwa secara umum konselor telah mampu mempraktekkan konseling singkat berfokus solusi. Hambatan-hambatan yang ada merupakan tantang dalam mempraktekkan pendekatan konseling baru. 


\section{SIMPULAN DAN SARAN}

\section{SImpulan}

Berdasarkan pembahasan di atas, maka simpulan yang dapat dibuat antara lain:

1. Sebelum pelatihan dilaksanakan, tim pelaksana menyusun buku panduan konseling singkat berfokus solusi.

2. Pelatihan dilakukan dalam dua kali pertemuan. Pertemuan pertama terbagi atas tiga sesi.

3. Evaluasi hasil pelatihan menunjukkan kepuasan dari seluruh peserta terhadap isi dan proses pelaksanaan pelatihan.

\section{SImpulan}

Berdasarkan simpulan di atas, maka hal-hal yang menjadi saran yaitu:

1. Setiap pelatihan membutuhkan persiapan dan sosialisasi yang baik.

2. Evaluasi hasil pelatihan perlu dilakukan secara periodik dan berkala.

\section{DAFTAR PUSTAKA}

Bachtiar, Amsal. (2012). Filsafat IImu Edisi Revisi. Jakarta: Raja Grafindo Persada.
Bandler, R. \& Grinder, J. (1975). The Structure of Magic I: A Book About Language and Therapy. California: Svience and Behavior Books Inc.

Charlesworth, J.R. \& Jackson, C.M. (2004). Solution-Focused Brief Counseling: An Approach for Professional School Counselor. Dalam Bradley T. Erford (Ed), Professional School Counseling: A Handbook of Theories, Programs \& Practice (hal. 139-148). Austin, TX: Pro-Ed, Inc.

Corey, G. (2009). Theory and Practice of Counseling and Psychotherapy $\left(8^{\text {th }}\right.$ Ed.). Belmont, CA: Brooks/Cole.

Departemen Pendidikan Nasional. (2007). Penataan Pendidikan Profesional Konselor dan Layanan Bimbingan dan Konseling dalam Jalur Pendidikan Formal. Jakarta: Departemen Pendidikan Nasional.

Lines, D. (2012). Brief Counseling in Schools: Working with Young People from 11$18\left(^{\text {th }} \quad\right.$ Ed.). London: Sage Publication.

McLeod, J. (2009). An Introduction to Counseling (4th $E d$.). New York: Open University Press. 